\title{
Kritika komunizma, liberalizma i znanstveno- tehnološke revolucije u djelima Bonifacija Perovića
}

Šimun Lončarević*

simun.loncarevic@gmail.com

https://orcid.org/0000-0002-6547-7809

Ivan Šestak**

isestak@ffrz.unizg.hr

https://orcid.org/0000-0002-2088-9041 https://doi.org/10.31192/np.19.2.5

UDK: 27-789.32Perović, B.

141.82

330.82

316.422 .44

Pregledni članak / Review

Primljeno: 18. veljače 2021.

Prihvaćeno: 31. ožujka 2021.

U radu se istražuje odnos Bonifacija Perovića prema liberalizmu, komunizmu i znanstveno-tehnološkoj revoluciji. Pripadajući personalističkom krugu hrvatskih katoličkih intelektualaca, Perović je prije i nakon Drugoga svjetskoga rata, na što ćemo staviti težište, napisao nekoliko rasprava $i$ studija iz političke $i$ socijalne filozofije, u kojima je podvrgnuo kritici temeljne idejne postavke i ciljeve $i$ komunizma i liberalizma, odnosno i kapitalizma, zaključivši da, iako prividno različite, obje političko-socijalne ideologije konvergiraju i materijalizmu i otporu kršćanskom svjetonazoru, što, kao krajnju posljedicu, ima degradaciju čovjeka. Toj kritici nakon Drugog svjetskog rata pridružio je kritiku znanstveno-tehnološke revolucije, koja postaje ideologija per se, te s prvim dvjema ideologijama čini svojevrstan materijalistički trokut.

Ključne riječi: Bonifacije Perović, društvo, komunizam, liberalizam, osoba, znanstveno-tehnološka revolucija.

\footnotetext{
* Šimun Lončarević, mag. ing. mech., mag. phil., Energetski institut Hrvoje Požar, Savska cesta 163, HR-10000 Zagreb.

** Prof. dr. sc. Ivan Šestak, Sveučilište u Zagrebu, Fakultet filozofije i religijskih znanosti, Jordanovac 110, HR-10000 Zagreb.
} 


\section{Uvod}

Dvadeseto stoljeće donijelo je, uz nedvojben civilizacijski napredak, razorne posljedice imperijalnih i totalitarnih politika, kojima u temelju stoje političke filozofije, koje možemo smatrati (iako na prvi pogled oprečnim) djecom prosvjetiteljstva: liberalnog individualizma i marksističkog socijalizma. Pridodamo li im fašizam i nacizam, s fetišima nacije i rase, dobivamo kao rezultantu dva najkrvavija rata u povijesti čovječanstva.

Katolička je crkva upozoravala na to što mogu izazvati takve politike, i to posebice enciklikama Rerum novarum Lava XIII. i Quadragesimo anno Pija XI, koji je, osim toga, 1931. godine osudio talijanski fašizam enciklikom Non abbiamo bisogno, a 1937. enciklikom Divini Redemptoris osudio komunizam, te naposljetku isto tako osudio nacizam enciklikom Mit brennender Sorge. Ukratko, katolička misao razvija se i homogenizira na neprihvatljivosti građanskih individualističkih i totalitarnih kolektivističkih društava, zauzimajući se za personalističko, komunitarno i pluralističko društvo nadahnuto kršćanskim vrijednostima slobode, ljubavi i bratstva.

Hrvatski katolički intelektualci promišljali su recentne političko-socijalne pokrete i ideologije, počevši od početka 20. stoljeća. Prvi koji se sustavnije prihvatio toga posla bio je fra Urban Talija, koji je već početkom stoljeća u svojim člancima i brošurama Socijalizam i socijalno pitanje (1906), Prigodom nekih konferencija u Dubrovniku o socijalnoj demokraciji (1906), Socijalna demokracija pred socijalnim pitanjem (1907), Socijalna demokracija prema socijalnom pitanju (1909) kritizirao ne samo marksizam, već i sve teorije ranoga socijalizma. Nakon toga izlaze brojne rasprave i studije, primjerice Josipa Gunčevića, Jurja Šćetinca, Milana Ivšića, Đure Gračanina, Hijacinta Boškovića, Dominika Barača, Stjepana Tomislava Poglajena i dr.

\section{1. Životopis i recepcija Bonifacija Perovića}

Među spomenutima bio je i franjevac Bonifacije Perović. Taj franjevac Provincije Sv. Jeronima u Zadru rođen je 24. studenoga 1900. u Arbanasima. Od 1911. do 1919. pohađao je gimnaziju u Dubrovniku, a zatim i studij teologije do 1923., kada je zaređen za svećenika. Godine 1928. upisuje doktorski studij na Institut Catholique u Parizu, gdje 1932. doktorira disertacijom »Radnička sredina i njezin ustroj«. Veći dio objavljen je tijekom 1932. i 1933. u francuskoj socijalnoj smotri Dossier de l'Action populaire. Tada razvija inozemne društvene veze, pa god. 1930. prvi put sudjeluje na kongresu Pax Romana u Münchenu, a potom još nekoliko puta sve do posljednjeg u Montevideu 1962. Godine 1936. imenovan je duhovnikom Hrvatskog katoličkog akademskog društva »Domagoj« (osnovanoga 1906. u Zagrebu). U svibnju 1945. napušta Hrvatsku, krenuvši 
u »tužno izgnanstvo i svjetsko podstanarstvo «. ${ }^{1}$ Prvo stiže u Rim, a zatim 1947. u Argentinu, gdje 1958. osniva Društvo hrvatskih katoličkih sveučilištaraca. Godine 1968. nastanio se u Bologni, gdje je preminuo 5. travnja 1979. godine. Njegovi su posmrtni ostatci 1995. godine preneseni u franjevačku grobnicu u Zadru.

Već prije Drugoga svjetskoga rata Perović je objavio nekoliko brošura protiv komunizma, boljševizma, marksizma i svih sličnih pojava, no isto tako i kapitalizma: Marksizam (1934), Kapitalizam (1934), Boljševizam (1935), Komunističke krilatice (1936), Komunizam (1937) te Kapitalizam i komunizam (1944), da bi poslije rata objavio više članaka i knjiga, među kojima su najvažnije Hrvatsko društvo u revolucionarnom procesu: naš čovjek i društvo u prijelomu povijesnog razdoblja (1971) i Društvo u svom ljudskom liku: vrijednosti i društvene snage nove hrvatske izgradnje (1979). Nažalost, njegova su djela i danas nepoznata ili slabo poznata, pa i politolozi i sociolozi, koji bi ih trebali poznavati, ne znaju za njih, iako je njegova misaona baština, kao i cjelokupna baština katoličke političke, socijalne i kulturne misli, ne samo kvantitativno obilna već i kvalitativno snažna te i danas izazovna za istraživanja. O njemu se od 1945. do 1990. u domovini nije smjelo pisati. Koliko-toliko njegov se rad pratio u iseljeništvu, no i tu većinom prigodice i informativno. Nakon 1990. znanstveno i stručno relevantno Perovićem se do sada intenzivnije bavio Ivan Čulo, najprije u biblioteci Glasa Koncila »Hrvatska katolička baština XX. st.« priredivši 2008. knjigu njegovih izabranih tekstova »Društveno-socijalne misli« te poslije objavivši i tematski članak. ${ }^{2}$ Kontekstualno se njime bavio u više članaka ${ }^{3}$ te $u$ nekoliko djela. ${ }^{4}$ Ukratko, rasprava o Peroviću još je manje-više plod istraživanja jednoga autora, iako je, kako se vidi pretragom na internetskim tražilicama, o njemu prigodice javno govoreno ili pisano u više navrata (Z. Gavran, S. Kljaić, V. Lončarević, Ž. Mardešić i dr.).

\footnotetext{
${ }^{1}$ Jakov JUKIĆ, Od radničkog pitanja do vizije hrvatskog društva. Znanstveni lik Bonifacija Perovića (1900.-1979.), Bogoslovska smotra, 67 (1997) 4, 473-502, 485.

2 Ivan ČULO, Personalistička vizija čovjeka i hrvatskoga društva Bonifacija Perovića u vremenu od 1941. do 1979., Obnovljeni život - časopis za filozofiju i religijske znanosti, 70 (2015) 1, 4153.

${ }^{3}$ Ivan ČULO, Utjecaj personalizma na hrvatske katoličke socijalne mislioce u 1930-im, Prilozi za istraživanje hrvatske filozofske baštine, 39 (2013) 2, 535-580; Recepcija Nikolaja A. Berdjajeva u Hrvatskoj tijekom 20. stoljeća, Prilozi za istraživanje hrvatske filozofske baštine, 41 (2015) 1, 91-170; Recepcija Emmanuela Mouniera u Hrvatskoj i bivšoj Jugoslaviji do 1965. godine, Nova prisutnost - časopis za intelektualna i duhovna pitanja, 15 (2017) 1, 5-28.

${ }^{4}$ Ivan CULO, Recepcija personalizma u Hrvatskoj tijekom XX. stoljeća, Zagreb, Alfa, 2019; Personalizam i Univerzalna deklaracija o ljudskim pravima, Beograd, Institut za evropske studije, 2019; Personalizam i ljudska prava, Zagreb, Alfa, 2020.
} 


\section{Kršćanstvo - temelj Perovićeve političke i socijalne filozofije}

Perović je kao katolički svećenik izobrazbu stekao na katoličkim visokim učilištima, koju je poslije nadogradio doktorskim studijem i stalnim proučavanjem filozofske, politološke, sociološke i druge literature. Perovićeva socijalna hijerarhija u tome je pogledu jasna: »Bez autentične čovjekove osobe nema ni prave obiteljske zajednice, kao prvotne društvene ćelije ljubavi i povjerenja, ali niti naroda kao moralno-kulturne zajednice." Susljedno, »svaka kriza, rastakanje i krivotvorenje osobnosti neizbježivo povlači krizu i dezintegraciju društvenih tijela«..$^{5}$ Ovdje možemo uočiti jasnu gradaciju i povezanost subjekata: osoba, obitelj, društvo, narod.

Perović je dakle izričit $\mathrm{u}$ tome da u razmatranju svake društvene problematike treba poći "prije svega s problema čovjekove osobe«, svjestan krize vrijednosti modernoga čovjeka, čija je biblijska slika o čovjeku kao »imago Dei« narušena i ugrožena. ${ }^{6}$ Najvećega protivnika takve slike i poimanja čovjeka on vidi u koncepcijama što ih nose »biološki monizam i dijalektički materijalizam«. Njihov je cilj čovjeka pretvoriti u masu, broj, kvantitetu. Zaključno, »samo onaj koji cijeni Boga Stvoritelja može cijeniti dostojanstvo svake osobe «. Č Čovjek se ne smije uporabiti kao sredstvo - on je svrha u sebi. ${ }^{8}$

To su polazišta s kojih Perović razvija svoju političko-socijalnu misao, intenzivno od vremena kada se bavio pisanjem disertacije »Radnička sredina i njezin ustroj«. Vrlo važnu podlogu u tome, osim reevangelizacijskoga djelovanja Hrvatskog katoličkog pokreta kroz kulturni, socijalni i politički rad, dalo mu je okruženje tijekom studija u Parizu, koji je tada bio središte kršćanske političke i socijalne misli, koju su kreirali ljudi poput Jacquesa Maritaina i Nikolaja Berdjajeva. Splet takvoga intelektualnoga odrastanja dao mu je želju, znanje i razumijevanje konteksta kojim će, s jedne strane, promicati i braniti kršćansku personalističku sliku čovjeka, a s druge strane, pravo Hrvata na svoju državu i viziju budućega hrvatskoga društva.

\section{Kritika sustava protivnih čovjekovoj naravi}

Kako je bilo rečeno, još prije Drugoga svjetskoga rata Perović je upozoravao na opasnost političkih ideologija koje su uzimale maha diljem Europe - socijalizma u komunističkom obliku i individualističkog liberalizma, kojima je

\footnotetext{
${ }^{5}$ Bonifacije PEROVIĆ, Hrvatsko društvo u revolucionarnom procesu. Naš čovjek i društvo u prijelomu povijesnog razdoblja, Barcelona, Knjižnica Hrvatske revije, 1971, 13.

${ }^{6}$ Isto, 10-12.

7 Bonifacije PEROVIĆ, Universalna deklaracija čovječjih prava prigodom njezine desetgodišnjice (1948.-1958.), Hrvatska revija, 9 (1959) 2, 131-135, 132.

${ }^{8}$ Usp. isto.
} 
oboma u korijenu materijalizam i antropocentrizam, a kritikama tih ideologija pridružuje i kritiku znanstveno-tehničke revolucije, koja, pod utjecajem tih ideologija, postaje vrijednost i cilj per se, te također čovjeka otuđuje od duhovnih vrijed nosti.

U spomenutim djelima objavljenima prije 1945. godine Perović posebice ističe da te ideologije, naizgled suprotne, konvergiraju te se, dapače, međusobno potiču i surađuju u rušenju kršćanskih vrijednosti i neprijateljstvu prema Crkvi, ${ }^{9}$ pri čemu treba imati u vidu da je »stariji brat« - individualistički liberalizam - otvorio put reakciji - marksističkom socijalizmu, koji je nasilno ispraznio radničke prostore od svake prisutnosti kršćanskoga utjecaja.

»Mi smo već spomenuli da je konfliktivnost dviju ideologija samo površna, pošto među njima ne postoji društveno-etička razlika, koja bi ih dovela do razilaženja aksiološke naravi, tj. u poimanju vrijednosti. Obje su zaokupljene oko stvari ovog svijeta i oko borbe za vlast te za svjetovna tržišta i oko toga totalitariziraju sve slobode i prava, ali uvijek složni protiv onih koji postavljaju 'totalno shvaćanje čovječjeg zvanja i njegovih različitih društvenih izražaja', protiv onih koji se protive da država i stranke nametnu ideologiju sredstvima, koja nužno vode u 'diktaturu nad duhom, najgorom od svih diktatura'. Oba ideološka sustava su složna u blokiranju kršćanskog događaja, na kojem je i nastala Europa i hrvatski narod, potiskujući ga izvana i iznutra. $\ll^{10}$

Oba sustava dakle ruše i napadaju Crkvu da bi odmaknuli čovjeka od kršćanstva, a zatim i od ideje Boga. Osnovna pogreška tih sustava proistječe iz uzvisivanja čovjeka na božanski red. Pritom, može se napomenuti, za razliku od komunističkoga otvorenoga i nasilnoga nijekanja Boga, da liberalni individualizam djeluje perfidno relativizacijom čovjeka kao slike Božje. ${ }^{11}$ Ista negacija čovjekove naravi, samo grublje, događa se i u totalitarnim sustavima nacizmu, fašizmu i komunizmu. Oni ne priznaju vrijednost čovjeka kao osobe, nego mu daju smisao i vrijednost samo kao dijelu ideologije, stranke, države, rase, klase...

\subsection{Kritika komunizma}

Perović se dakako posebno kritički osvrnuo na marksizam i njegovo materijalističko-ateističko gledište, koje u konačnici, kao i individualistički liberalizam, rezultira materijalističkim relativističkim i utilitarističkim moralom. Kritizirajući ga pod inačicama pojmova marksizam, boljševizam, komunizam, socijalizam, stavlja ga u kontekst konkretne povijesti hrvatskoga naroda, koja je bitno obilježena kršćanskom tradicijom zapadne Crkve. Prvi je od svih sla-

\footnotetext{
${ }^{9}$ Usp. Bonifacije PEROVIĆ, Moskva ili Rim, u: Perović, Društveno-socijalne misli, prir. I. Čulo, Zagreb, Glas Koncila, 2008, 51-52.

${ }^{10}$ Bonifacije Perović, Društvo u svom ljudskom liku. Vrijednosti i društvene snage nove hrvatske izgradnje, Barcelona, Knjižnica Hrvatske revije, 1979, 340-341.

${ }^{11}$ Usp. Perović, Moskva ili Rim..., 42.
} 
venskih naroda prihvatio kršćanstvo, a nakon 1054. godine ostao je u krilu Katoličke crkve. Iako je bio okružen različitim utjecajima sa Zapada i Istoka, primarno i temeljno je »hrvatski narod bio oblikovan kao član zapadnog kulturnog kruga.$^{12} \mathrm{Na}$ njegovu kulturu su osobito djelovali prvo benediktinci, zatim franjevci, koji su čak i za vrijeme Turaka ostali s narodom u okupiranim područjima, zatim dominikanci, isusovci i pavlini te, dakako, svećenstvo u cjelini. Slobodni krajevi su sudjelovali u kulturnom, duhovnom i vojnom razvoju Europe i time je »ideja naše povijesti (...) jasno obilježena kao vjernost kršćanskoj Europi ${ }^{13}$ Komunizam će to nastojati poništiti i stoga ga Perović već prije rata prepoznaje kao opasnost, koja se nakon rata pokazala u svoj svojoj razornoj snazi u hrvatskom narodu.

U prvospomenutoj knjižici Marksizam Perović uočava utopijski karakter komunizma ustvrdivši da »Marx i Engels nijesu izgradili svoju materijalističku teoriju iz podrobnog proučavanja povijesti«, nego su je »natezali« da bi opravdali svoje teorije. ${ }^{14}$ Osim toga, boljševistička utopija čovjeku obećava nestanak države i savršeno društvo, no "promjene društvene i političke strukture ne mogu promijeniti čovjeka«. ${ }^{15}$

Kritiku komunizma Perović je, u novim okolnostima, nastavio u emigraciji, posebice u knjizi Hrvatsko društvo u revolucionarnom procesu. Naš čovjek $i$ društvo u prijelomu povijesnog razdoblja izdanoj 1971., koja, podijeljena u tri dijela - »Revolucionarni proces u Hrvatskoj «, »Preustrojstvo društvenih ustanova« te »Principi, vrline, ustanove i društvene snage za obnovu i novu izgradnju Hrvatske« - ima ne samo karakter historiološke analize već i historiozofski karakter, odnosno budućnosni, futuristički aspekt. Posebno je važan »Uvod«, gdje Perović postavlja problem i izlaže teze. Polazi od toga da je poslije rata hrvatski narod bio uključen u sustav koji je doveo sve u pitanje; od ljudske osobe do cijelog društva. Nekad je vizija života bila »transcendentna, usmjerena s onu stranu života «, ${ }^{16}$ dok se dolaskom komunizma ta slika drastično promijenila. Komunizam se predstavio kao veliko očekivanje naroda, a dogmatski kao »novo otkupljenje čovječanstva« ${ }^{17} \mathrm{U}$ Hrvatskoj komunizam nije donio samo $» k v a n t i t a t i v n u$ « promjenu novoga političkog sustava te ubijanja i protjerivanja Hrvata, nego i »kvalitativnu« promjenu, provodeći sustavnu »povijesno-kulturnu amneziju «, lišavajući Hrvate njihove povijesti i kulture. ${ }^{18}$ Stoga, iako je komunizam riješio neka kontingentna pitanja, istodobno je ugrozio ona esencijalna, a »prava, dugoročna, ali i konačna bitka se vodi zapravo u tim metafi-

\footnotetext{
${ }^{12}$ Perović, Hrvatsko društvo u revolucionarnom procesu..., 39.

${ }^{13}$ Isto, 40.

${ }^{14}$ Bonifacije PEROVIĆ, Kritika historijskog materijalizma, u: isti, Društveno-socijalne misli..., 55.

${ }^{15}$ Bonifacije PEROVIĆ, Boljševizam, u: isti, Društveno-socijalne misli..., 66.

${ }^{16}$ Perović, Hrvatsko društvo u revolucionarnom procesu..., 8.

${ }^{17}$ Isto, 8.

${ }^{18}$ Isto, 27-28.
} 
zičkim temeljima našeg društva «. ${ }^{19}$ Perović se slaže s onima koji smatraju da u uspostavi nove Jugoslavije nije sudjelovao hrvatski narod, što je teza koju su još tijekom rata isticali katolički intelektualci (I. Bogdan, T. Mortigjija, M. Magdić i dr.).

Perović dijeli komunističko društvo u tri skupine, ukazujući na to da stare slojeve društva komunizam nije samo dokinuo, nego ih je i zamijenio novima. U prvom redu navodi Partiju i one koji su joj se pridružili prije i tijekom revolucije. Zatim pridolaze oni koju su se kasnije pridružili komunističkom režimu, dok su naposljetku oni koje režim progoni. ${ }^{20}$ Ukratko, komunističko društvo okarakterizirao je kao

»strogo hijerarhizirano društvo s osobnom vlašću na vrhu uz postojanje društvenih nejednakosti i vrlo istaknutih povlastica, ali nadasve s apsolutnom odsutnošću sudjelovanja i suodlučivanja radnog naroda na vrhu«. ${ }^{21}$

Prva žrtva komunizma bila je obitelj, koja je za Perovića »prva ustanova« u kojoj osoba prolazi "prvu školu životnih spoznaja, životnih načela i iskustva «. ${ }^{22}$ Ona je pogođena i posredno i neposredno; posredno od općenitih promjena $u$ društvu, a neposredno od pojedinaca i ideologija koji žele promijeniti dotadašnje funkcioniranje obitelji. Njezin je značaj u komunizmu profaniran uz rastave brakova i ozakonjenje pobačaja. Zbog toga su nastupile brojne promjene u obiteljima, od čega je najznačajnija oslabljena nutarnja veza same obiteljske zajednice. Obitelj je svedena na užu obitelj u kojoj su svi članovi u pravilu prezauzeti da bi obitelj kao ustanova proizvodila. Zbog svih tih utjecaja obitelj više nema odgojnu funkciju kao nekad. ${ }^{23}$ Posljednji ostaci tradicionalnih obitelji nalaze se na selu i zato $»$ komunističkom sustavu ne prija seljaštvo« ${ }^{24}$

Druga žrtva je bila privatno vlasništvo, koje je obitelji pružalo »zdrav životni prostor,$^{25}$ a samim time otet je i $»$ materijalni potporanj slobodnom nastupu čovjeka i obiteljskoj samostalnosti«. ${ }^{26}$ Privatno vlasništvo nije samo proizvod društva, nego postoji »iz ontološkog prvenstva čovjeka naprama društvenim tijelima « ${ }^{27}$ riječ je dakle o prednosti osobe pred društvom. Pravo na privatno vlasništvo mora biti raspodijeljeno "po principu distributivne pravde«, prema učinku i zaslugama, ali i "po komunikativnoj pravdi, da svatko ima najpotrebnije . $^{28}$ Vlasništvo ima funkciju i kao pravo i kao dužnost pravilnog raspolaganja. Zbog komunističkoga zadiranja u privatno vlasništvo ono »gubi

\footnotetext{
${ }^{19}$ Isto, 132.

${ }^{20}$ Usp. isto, 221.

${ }^{21}$ Isto, 224.

22 Isto, 147.

${ }^{23}$ Usp. isto, 148-149.

${ }^{24}$ Isto, 158.

${ }^{25}$ Isto, 67.

${ }^{26}$ Isto, 164 .

${ }^{27}$ Isto, 165.

${ }^{28}$ Isto, 166.
} 
svoju nekadašnju ulogu« ${ }^{29}$ čime i obitelj gubi materijalnu sigurnost. Time se napada i čovjekov rad, koji je »čovjekovo plemenito i neotuđivo pravo i dužnost«..$^{30}$

Ipak, unatoč tadašnjoj još čvrstoj vladavini komunizma, Perović zaključuje da komunizam, ne samo u Jugoslaviji nego i u čitavom svijetu, prolazi kroz duboku krizu. Osnovni razlog tomu je što su komunisti pokušali ostvariti neko imaginarno društvo, u kojemu bi promijenili samu ljudsku narav. ${ }^{31}$ Što se komunizam više primjenjuje u praksi, to postaje očitijim da je riječ o neprimjenjivoj teoriji. U praksi ga je pregazilo vrijeme jer se zapadni sustav demokracije i kapitalizma pokazao uspješniji u iskorjenjivanju siromaštva, pogotovo u primjeni tehnološkoga napretka. ${ }^{32}$ No i kad bi se praktični rezultati ostavili postrance, komunistička revolucija već je u početku bila osuđena na propast jer životno iskustvo pokazuje da ljudi ne mogu neprestano biti u borbi za neka apstraktna obećanja o boljoj budućnosti. Nadalje, dok se revolucija razvije, organizira, uspostavi i započne, svijet je već »promijenio svoje lice« te »na taj način evolucija ispražnjuje sadržaj revolucije«. ${ }^{33}$

Lucidnu kritiku komunizma odnosno marksizma nastavio je Perović i u djelu Društvo u svom ljudskom liku: vrijednosti i društvene snage nove hrvatske izgradnje. Tu posebice ističe da se marksizam i kršćanstvo razlikuju u samim temeljima i da su njihove razlike bitne. Čak naizgledne sličnosti raskrinkava kao razlike, jer za njega marksističko shvaćanje čovjeka rezultira time što »završava blokiranjem slobode i istinskog oslobođenja.$^{34}$ Navodi da su marksizam, i njegova primjena - komunizam, nastali kao reakcija na kapitalizam, koji »rađa nezasitni duh sticanja..., a danas znamo da rađa i komunizam «. ${ }^{35}$ Premda i kršćanska teologija i marksizam shvaćaju čovjeka kao društveno biće, Marx se »odjeljuje od početnog socijalizma« i postavlja nadgradnje »ideološke» i »ekonomske naravi«, čime se pokazuje da »marksizam predstavlja optimizam o kolektivnom čovjeku da bi time prikrio radikalni pesimizam o čovjekovoj osobi ${ }^{36}$

Nadalje, dok marksizam i kršćanstvo predstavljaju početno stanje čovjeka kao nevinoga bića, ipak »ono što je za kršćanstvo pala ljudska egzistencija po grijehu neposluha, za marksizam je otuđena egzistencija po povijesno-političkim strukturama «. ${ }^{37}$ Bitna je razlika i u razumijevanju otkupljenja čovjeka. Dok kršćanstvo čovjeka stavlja u središte vlastitoga oslobođenja, marksizam na njega gleda poglavito kao na dio revolucije, čime bi automatski bio otkupljen kao

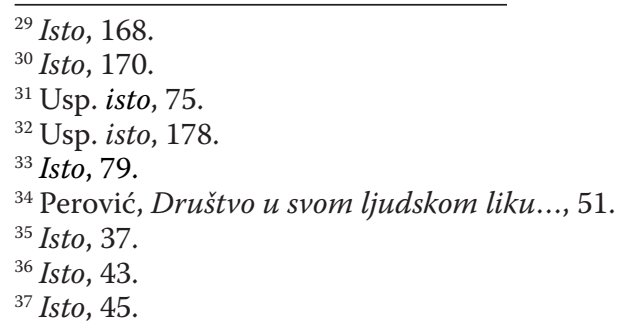


njezino sredstvo. Prema kršćanskom nauku, pad čovjekov je počeo u Adamu, a zlo se, između ostaloga, nalazi u čovjeku samom, čime i »oslobođenje ovisi, dakle, od čovjeka « $^{38}$ - ono je osobno i slobodno. Eshatološki je kršćanstvo također radikalno različito od marksizma. Ključni dio kršćanske eshatologije je nada, koja je »osobna i radi toga poziva čovjeka da je ostvari po svojoj osobnoj odluci«, dok je u »sekulariziranoj komunističkoj nadi čovjek osobno nemoćan i neodgovoran $\ll{ }^{39}$ Stoga je komunistička revolucija promašena jer »nijedna revolucija ne oslobađa automatski čovjeka, nego samo mijenja vanjske strukture i gospodare«, a »oslobođenje nikada ne nastaje po mržnji, nego po ljubavi« ${ }^{40}$

\subsection{Kritika liberalizma $i$ kapitalizma}

Perović je isto tako kritički pisao o liberalizmu, odnosno liberalnoj demokraciji te o kapitalizmu, kao njegovu socijalno-gospodarskom izdanku. »Zabluda dakle liberalne demokracije«, piše u knjizi Društvo u svojemu ljudskom liku,

»nalazi se u njezinoj socio-filozofskoj pretpostavci individualizma, što neizbježivo vodi do kolektivizma i komunizma, jer nijedan ne računa s potpunom čovječjom osobom, pa tako ni o ljudskim zajednicama, ni, prema tome, o društvenoj stvarnosti. To bi bio razlog da oni ne vode do usklađenog, harmoničnog i uravnoteženog društva; njihov pak veliki tehnički i privredni razvoj nije u službi općeg čovječanskog razvoja, nego radije u službi i na korist neke interesne skupine ili klase. « ${ }^{41}$

Perović je slične misli ispisao i mnogo prije. Tako još 1931. u članku »Moskva ili Rim« ustvrđuje kako je

»individualni (odnosno individualistički - prim. a.) liberalizam XIX. vijeka zadnja faza humanističke epohe. On je pokazivao na svim područjima očite simptome skore katastrofe. Štoviše, on već po svojoj naravi i po načelima koje je propovijedao nije mogao drugamo dospjeti nego u autonegaciju i autodestrukciju. Simptomi njegove nemoći i skoroga raspadanja bili su njegova beznačelnost, nutarnja kontradikcija i bolećivi skepticizam. Na vjerskom području individualni liberalizam je zabacio Vječnu Istinu Svemogućeg Boga i tim se odcijepio od duhovnog centra - Crkve. (...) Tim je nutarnji život modernog čovjeka odsječen od svog najneophodnijeg i najdubljeg principa, po kojem je mogao zaroniti u Apsolutno, u Biće nad bićima, u Vrednotu nad vrednotama. Dakle za liberalni liberalizam ne postoji nikakva apsolutna vrijednost. Ali pošto društvo, pa bilo to i ovo moderno, mehanizirano, ne može opstojati bez uređenja međusobnih odnosa, 'istina' će biti dekretirana. Istina je zamijenjena svemoćnim Brojem po načelu: Gdje je više glasova, onamo je istina. (...) Prvenstvo je dao ekonomiji, produkciji bogatstva, koje uvjetuje sav javni život i upravlja njime. I politički

\footnotetext{
${ }^{38}$ Isto, 49.

${ }^{39}$ Isto, 47.

${ }^{40}$ Isto, 50-51.

${ }^{41}$ Perović, Društvo u svom ljudskom liku..., 335.
} 
život se klanja kapitalističkom mamonu. Štoviše, i kod modernih nacionalističkih pokreta nalazi se na dnu ekonomsko pitanje. Evropa i Amerika postadoše materijalističke. Ta što je primat materijalnih dobara nad duhovnim vrednotama, ako ne historijski materijalizam. Historijski materijalizam ne nalazi se više samo u kojoj god usijanoj revolucionarnoj glavi, on je danas aktiviran $u$ čitavom zapadnjačkom javnom životu. Marxov historijski materijalizam nije zapravo drugo, nego neke vrsti kodifikacija, rezime filozofije njegovog i našeg vremena. ${ }^{42}$

Isto duhovno podrijetlo individualističkoga liberalizma i marksizma te njihovo neprijateljstvo prema kršćanstvu ističe Perović dosljedno i u svojoj posljednjoj knjizi:

»To dokazuje i uporna, dugotrajna, kivna agresivnost marksolenjinizma, kao i najnoviji bijes i kulturni terorizam europskih ljevičara na Boga, na Crkvu, što ustvari znači priznati hipotezu postojanja drugog apsoluta, u radikalnoj međusobnoj suprotnosti, nespojivosti i nepomirljivosti. Tu temu, kako je poznato, zapravo je inaugurirala liberalna buržoazija, svojom srdžbom na kršćanski događaj, koju preuzima marksizam. (33 $^{4}$

Kritika je dakle jasna da jasnija ne može biti!

$\mathrm{Na}$ to se oslanja i kritika kapitalizma, u kojemu isključivo vlada pravilo natjecanja i pozivanje na čovjekovu apsolutnu slobodu od svih veza. »Egoizam je njegova vjera. « ${ }^{44}$ Takva sloboda, življena kao sebičnost, uključuje i slobodu od bilo kakva uplitanja vjere, poglavito Crkve. Čovjek, dakle, mora na neki način biti oslobođen od Crkve. On sebe, time i svoj duh, podvrgava materiji u nadi da će time zavladati nad (vlastitom) prirodom. U ekonomskom smislu, to nije poredak čovjekovih potreba, nego profita. Proizvodnja je »od svoje prvotne zadaće postala anarhistična, bez mjere, bez moralnog držanja ${ }^{45}$ Novac je preuzeo primat nad svime ostalim i »potpuno materijalizirao stil života«, a moderna država se $» k a o$ rob podvrgava ljudskoj pohlepi ${ }^{46}{ }^{6} \mathrm{Na}$ Zapadu stoga detektira problem nedostatka interesa za privatni i javni moral, čak nastojanje da se od »nemorala učini dobar posao «. ${ }^{47}$

Zbog svega toga Mile Vidović, jedan od recenzenata njegove posljednje knjige, s pravom ustvrđuje da Perović i na kapitalizam i komunizam gleda kao na dva loša ekstrema. ${ }^{48}$

\footnotetext{
${ }^{42}$ Perović, Moskva ili Rim..., 42-44.

${ }^{43}$ Perović, Društvo u svom ljudskom liku..., 305.

${ }^{44}$ Bonifacije PEROVIĆ, Kapitalizam kao društveni sustav, u: isti, Društveno-socijalne misli..., 61.

${ }^{45}$ Isto, 63.

${ }^{46}$ Bonifacije PEROVIĆ, Mamonizam, u: isti, Društveno-socijalne misli..., 85.

${ }^{47}$ Perović, Hrvatsko društvo u revolucionarnom procesu..., 239.

${ }^{48}$ Usp. Mirko VIDOVIĆ, Bonifacije Perović: Društvo u svom ljudskom liku, Hrvatska revija, 30 (1980) 1, 122-128.
} 


\subsection{Potencijal i opasnosti znanstveno-tehničke revolucije}

Osim komunizma, na hrvatsko društvo, ali i na druga društva, snažno utječe znanstveno-tehnička revolucija. Ona, prema Peroviću, s komunizmom i liberalizmom tvori svojevrstan materijalistički trokut i oblikuje sociopolitički poredak svijeta. Revolucija znanosti i tehnologije uistinu je globalna. ${ }^{49}$ Ta nova civilizacija

»juri velikom brzinom i zapljuskuje čitav globus, ne pruža nam neki unaprijed gotov poredak, iako i ona predviđa neka stanja, kao neizbježive posljedice tehnološkog usavršenja, ali ipak zavisi od slobodnih ljudi, da njezine spoznaje, zakone i elemente otmu tehničkoj determiniranosti i da ih humaniziraju«. ${ }^{50}$

Pohvaljujući znanost kao pokretača koji je čovjeku olakšao ovozemaljski život, jer je on sada »bujniji i pogodbeno bogatiji «, ${ }^{51}$ Perović napominje da ona u sebi sadrži »težnju k pozitivizmu «. ${ }^{52}$ Znanost i tehnika imaju zavodljivu moć, osobito na mlade, koja ih može obuzeti toliko da smisao života vide samo u takvom materijalističkom sustavu. Na općoj razini problem je što postoji »neravnoteža između materijalnoga i duhovnoga, između kvantitativnog skoka, a bez moralnoga «. ${ }^{33}$ To rezultira time da je novi tip čovjeka moralno i psihološki »rastrgan«, nalazi se bez potpore i putokaza u duhovnom životu pa u tom području najčešće »nastupa iracionalno «. ${ }^{54}$ Znanost ne smije čovjeka pretvoriti $\mathrm{u}$ mehanički dio sustava, iz njega na neki način istisnuti ono što je naravno čovječje, nego treba imati na umu povlašteno čovjekovo mjesto, stoga se »ima promatrati i prosuđivati pod moralnim vidom čovječjih vrijednosti«. ${ }^{55}$ Vrlo precizno, gotovo proročanski, napominje da nove metode komunikacije lišavaju ljude »dubine i topline« nekadašnjih odnosa, nudeći mu umjesto toga širok opseg poznanstava, zbog čega »se čovjek nutarnje osamljuje i osiromašuje «. ${ }^{56}$

Kao jednu od opasnosti znanstveno-tehničke revolucije Perović navodi determinizam, koji bi čovjeka nasilno uvrstio u već pripremljeni sustav. On priznaje da stanovita doza determinizma ima smisla jer na čovjeka »utječe klima (...), zakoni gospodarstva (...), kao i tehnički razvoj«, no postavlja pitanje mogu li se uzeti u obzir kao toliko utjecajne da bi čovjeka »lišile slobode do te mjere« da bi se čovjek samo »pustio niz vodu $\aleph^{57}$ te zaključuje da se ne smije postaviti alternativa apsolutne »prisile ili slobode $«{ }^{58}$ nego se mora čovjeka gledati u nje-

\footnotetext{
${ }^{49}$ Usp. Perović, Hrvatsko društvo u revolucionarnom procesu..., 95.

${ }^{50}$ Isto, 137.

${ }^{51}$ Isto, 139.

${ }^{52}$ Isto, 99.

${ }^{53}$ Isto, 235.

${ }^{54}$ Isto.

${ }^{55}$ Isto, 102.

${ }^{56}$ Isto, 104.

${ }^{57}$ Isto, 245.

${ }^{58}$ Isto.
} 
govoj sveukupnosti. S gledišta determinizma moralni pojmovi bi izgubili svoje značenje, a »moral nadilazi znanost«, pa »kad bi pozitivne znanosti obuhvaćale sav život i rješavale sva životna pitanja, tada bi determinizam bio istinit i na svijetu ne bi bilo morala«. ${ }^{9}$

Zaključno, dvostruki revolucionarni proces znanosti i u Hrvatskoj formira novi tip čovjeka, koji će »biti uronjen u znanost« ${ }^{60}$ To je jedan od razloga što, kako vrijeme prolazi, »komunizam kao ideologija i sustav (...) polako otiče (...), a mjesto njega naši ljudi sve snažnije podliježu stilu života civilizacije sa Zapada ${ }^{61}$ jer je Zapad u tehnološkoj revoluciji superiorniji, ne samo boljim tehničkim rješenjima (bolji je zapadni automobil od istočnoga), nego i omogućavanjem široke i sve jeftinije dostupnosti proizvoda. Slovenija je stoga u Jugoslaviji najnaprednija jer je »najisturenija « prema Zapadu, a zatim dolazi Hrvatska, u koju svake godine dolazi sve više turista sa Zapada, i naposljetku stoga što su mnogi Hrvati otišli živjeti u zapadne zemlje, odakle donose tu kulturu u Hrvatsku. Stoga »nije pretjerano ustvrditi da je komunistički mit i privlačivi čar njegove ideologije uglavnom demitiziran u dušama naših ljudi i postavljen na svoje pravo mjesto ${ }^{62}$

\subsubsection{Razvoj i progres}

U djelu Društvo u svom ljudskom liku: vrijednosti i društvene snage nove hrvatske izgradnje Perović je pozornost posvetio i razlici između pojmova razvoja i progresa. Razvoj za njega označava nešto što ima izvorište u čovjeku i njegovoj slobodnoj volji. Budući da je vođen slobodom, nije linearan i jednosmjeran. S druge strane, progresom smatra onim što je nametnuto mitom o tome da čovjek vlastitim snagama može postići sve kroz znanstveno-tehnički napredak. ${ }^{63}$ Industrijsku revoluciju kao glavni čimbenik karakterizira materijalni napredak, no napominje da je ona rezultat moderne filozofije, koja je čovjeka proglasila »slobodnim individuumom «. ${ }^{64}$ Ona tvori mišljenje da je razvoj shvaćen samo kao progres, što je rezultiralo da se »ljudi sve više osjećaju nelagodno i nesigurno«, a život im »postaje besmislen«, što bi značilo da se »progres razvija protiv čovjeka.$^{65} \mathrm{U}$ svjetlu tih misli gospodarski razvoj ne smije biti samo povećanje moći i prihoda nego poglavito »u službi čovjeku i društvu, integralnom čovjeku« ${ }^{66}$ On se, nažalost, pretvorio $u$ »oportunistički, hedonistički i pragmatični mentalitet«, koji za opravdanje navodi materijalna postignuća. ${ }^{67}$

\footnotetext{
${ }^{59}$ Isto, 250.

${ }^{60}$ Isto, 233.

${ }^{61}$ Isto, 219.

${ }^{62}$ Isto.

${ }^{63}$ Perović, Društvo u svom ljudskom liku..., 115-116.

${ }^{64}$ Isto, 118.

${ }^{65}$ Isto, 121.

${ }^{66}$ Isto, 123.

${ }^{67}$ Isto.
} 


\subsubsection{Položaj i uloga mladeži}

Dinamičnost je bitna oznaka današnjega društva. Dok je nekad društvo napredovalo po promjenama koje su išle same po sebi i po zakonima evolucije i rasta, »novo znanstveno tehničko društvo je vrlo pokretljivo, puno brzih procesa i kvantitativnih skokova ${ }^{68}{ }^{6}$ Stoga u sklopu rasprave o znanstveno-tehničkoj revoluciji Perović pojedine dionice svojih djela posvećuje mladeži, najpodložnijoj znanstveno-tehničkom napretku i otvorenoj duhu novoga. Mladež je naime ta koja mora iznijeti nužne promjene u društvu, jer »bolje osjeća nego stara pokoljenja potrebu i zahtjev novog vremena«. ${ }^{69}$ Svaki naraštaj mladih donekle odbija pokoravanje starim običajima, a »danas želi sam sebi izgraditi novi uzor života « ${ }^{70}$ jer je ona $»$ industrijska mladež ili rađanje novog tipa čovjeka «. ${ }^{71}$ Roditelji više ne odgajaju svoju djecu, jer »odgajati nekoga znači, prije svega, predlagati mu i priučiti ga na određeni red vrijednosti, omogućiti mu kritički sud o životnoj stvarnosti «. ${ }^{72} \mathrm{Na}$ Istoku pak, u komunističkim zemljama, mladima se uglavnom kaže »da treba podnijeti sve žrtve za izgradnju idealnog socijalističkog društva koje dolazi«. ${ }^{73} \mathrm{U}$ oba slučaja riječ je o »homo oeconomicus «, kojega drži »najopasnijim mitom « ${ }^{74} \mathrm{U}$ svjetlu svih promjena smatra da mladi prebrzo odrastaju i da uz želju za slobodom ne razmišljaju o odgovornosti i životnoj borbi koju sloboda i odrasla dob nose. Ipak, njegovo razmišljanje je optimistično i pozitivno, jer

»na tom putu se mladi čovjek osjeća olakoćen, jer se smatra lišenim stare mudrosti, iskustva i pravila punih opreza svojih starih, bez pritiska, dakle, svoje bliže okoline i svih obaveza prema svojoj predaji, a to znači u isto vrijeme, da ulazi u život neopterećen od mnogo toga što je nekada priječilo razvoj pune osobnosti i ostvarenje pravednijeg društvenog poretka«. ${ }^{75}$

\section{Zaključak}

Iz svega rečenoga očito je Perović mnogo vremena i energije uložio u razradu kritike aktualnih političkih filozofija i sustava. Kritizirajući nedostatke Istoka i Zapada, zaključuje da su oba neuspješna u ukalupljivanju čovjeka, jer se »nije rodio kolektivni čovjek na Istoku, ni konformist na Zapadu, nego se i jedni i drugi bude protiv sustava bez slobode.$^{76}$ Svaki čovjek mora odvagnuti

\footnotetext{
${ }^{68}$ Perović, Hrvatsko društvo u revolucionarnom procesu..., 266.

${ }^{69}$ Isto, 196.

${ }^{70}$ Isto, 198 .

${ }^{71}$ Isto, 231.

${ }^{72}$ Isto, 200.

${ }^{73}$ Isto, 206.

${ }^{74}$ Isto, 207.

${ }^{75}$ Isto, 232.

${ }^{76}$ Isto, 253.
} 
i kritički preispitivati što je vrijedno, a što ne, da bi svojim izborom mogao »oblikovati našu potpunu osobnost i bolji život u zajednici«.77

U hrvatskom društvu nakon 1945. godine idejna strujanja svrstava Perović $\mathrm{u}$ »tri orijentacije«: agnostičko-liberalnu, socijalističko-laicističku i vjersku, teističku. ${ }^{78}$ Budući da nijedna ne može prevladati, Perović ključnim uvjetom kreiranja budućnosti i novoga društva vidi u suradnji triju struja. »Ili konkretno, nama je potrebna zajednička volja svih vjernika, liberalaca i socijalista. $^{79}$ Pritom je bitno »pronaći zajednički rječnik«, »osloboditi se svake apsolutizacije i biti tolerantan«, a morala bi se i »odbiti logika dviju vrijednosti, to jest ljevicadesnica ${ }^{80} »$ Novi hrvatski naraštaj « ima dužnost okupljanja i izgradnje »novog hrvatskog društva. ${ }^{81}$ Samo doprinosom svih snaga moguće je to ostvariti.

\section{Šimun Lončarević* - Ivan Šestak*** \\ Bonifacije Perović's Critique of Communism, Liberalism and the Scientific and Technological Revolution}

\section{Summary}

The paper investigates the attitude of Bonifacije Perović towards liberalism, communism and the scientific and technological revolution. Belonging to the personalist circle of Croatian Catholic intellectuals, Perović wrote several treatises and studies in political and social philosophy before and after the Second World War, in which he criticized the basic ideological setting and goals of both communism and liberalism and capitalism, respectively. concluding that, although seemingly different, both political-social ideologies converge on both materialism and resistance to the Christian worldview, which, as a final consequence, degrades man. He joined this critique after the Second World War with the critique of the scientific and technological revolution, which became an ideology per se, and with the first two ideologies formed a kind of a materialist triangle.

Key words: Bonifacije Perović, communism, liberalism, person, scientific and technological revolution, society.

(na engl. prev. Šimun Lončarević)

\footnotetext{
${ }^{77}$ Isto.

${ }^{78}$ Perović, Društvo u svom ljudskom liku..., 331.

${ }^{79}$ Isto, 347.

${ }^{80}$ Isto, 332-333.

${ }^{81}$ Isto, 347.

* Šimun Lončarević, mag. ing. mech., mag. phil., Energy Institute Hrvoje Požar, Savska cesta 163, HR-10000 Zagreb, Croatia; e-mail: simun.loncarevic@gmail.com.

** Ivan Šestak, PhD, Full Prof., Faculty of Philosophy and Religious Studies, Jordanovac 110, HR10000 Zagreb, Croatia, e-mail: isestak@ffrz.unizg.hr.
} 